\title{
Effect of Pink Pigmented Facultative Methylotrophs on Seedling Emergence and Vigour of Rice (Oryza sativa L.)
}

\author{
J. C. Aswathy ${ }^{1}$, P. Shalini Pillai ${ }^{*}{ }^{*}$ Jacob John $^{2}$ and K. S. Meenakumari ${ }^{3}$ \\ ${ }^{1,2}$ Department of Agronomy, Kerala Agricultural University, College of Agriculture, \\ Vellayani, Thiruvananthapuram, Kerala, India \\ ${ }^{3}$ Kerala Agricultural University, Integrated Farming System Research Station, Karamana, \\ Thiruvananthapuram, Kerala, India \\ ${ }^{4}$ Department of Agricultural Microbiology, Kerala Agricultural University, College of \\ Agriculture, Vellayani, Thiruvananthapuram, Kerala, India \\ *Corresponding author
}

\section{A B S T R A C T}

\begin{tabular}{|l|}
\hline Ke y w or d s \\
Seedling vigour, \\
seed treatment, \\
PPFM, rice.
\end{tabular}

A study was conducted to assess the effect of pink pigmented facultative methylotrophs (PPFM) on the seedling emergence behavior of rice, during the summer season at the Integrated Farming System Research Station, Karamana, Thiruvananthapuram, Kerala. The experiment was laid out in completely randomized design with six treatments and four replications. The treatments consisted of five superior isolates of PPFM (PPFM 16, PPFM 26, PPFM 35, PPFM 37, PPFM 38) compared against a control (distilled water). Irrespective of the PPFM isolates hundred per cent emergence was observed. A higher emergence rate index (160) was observed for rice seeds treated with PPFM 38. Seedling root length recorded significant variation among the different PPFM isolates, with PPFM 38 proving to be superior. The same trend was observed with dry weight of seedlings also. The seedling vigour expressed as vigour index I and II were observed to be superior with seed treatment of PPFM 38 and PPFM 37 respectively. When compared to distilled water, seed treatment with PPFM elicited better seedling characters. The study revealed that seed treatment with PPFM could enhance the emergence and seedling vigour of rice.

\section{Introduction}

Rice is the most important human food crop in the world, directly feeding more people than any other crop. The rice cultivation dates back to 7000- $5000 \mathrm{BC}$ and the earliest archeological evidences comes from Central and Eastern China. Rice has fed more people over a longer time than any other crop and for more than half of the humanity "rice is life". Rice is semi- aquatic in nature and is usually grown under flooded condition conventionally and is one among those crops which has very little adaptation for water stress and shows remarkable sensitivity to drought (Kamoshita et al., 2008). In the present day scenario of climatic change, rice is affected by water scarcity and drought. 
In the course of mitigating the effect of water stress and drought comes the importance of microorganisms, among which the Pink Pigmented Facultative Methylotrophs (PPFMs) plays an important role.

Pink Pigmented Facultative Methylotrophs (PPFMs) belong to the genus Methylobacterium and is gram negative, rod shaped, strictly aerobic in nature. They generally possess a pink pigmentation due to carotenoid synthesis and hence the name PPFM (van Dien et al., 2003). PPFM is capable of occupying different habitats such as soil, water, leaf surfaces, grains etc. due to its greater phenotypic plasticity.

Several studies have been reported by Freyermuth et al., (1996) for the interaction of the Methylobacterium sp. with different plant species by regulating phytohormone production. They were found to produce phytohormones such as cytokinins and auxins which promotes cell division and elongation respectively. The effect of PPFM on the germination, growth, yield and yield attributes of various crops such as tomato, agave etc. has been identified through various studies undertaken at different parts of the world.

The present investigation was carried out to evaluate the effect of Pink Pigmented Facultative Methylotrophs (PPFM) on rice seedling emergence and vigour in aerobic rice.

\section{Materials and Methods}

A pot culture experiment was conducted at Integrated Farming System Research Station , Karamana, Thiruvananthapuram, Kerala, during summer, 2019 -2020 with the medium duration rice variety MO16 (Uma). The experiment was laid out in completely randomized design with six seed treatments replicated four times. The treatments comprised five promising isolates of PPFM obtained from the Department of Agricultural Microbiology, College of Agriculture, Vellayani, and a control (distilled water). The isolates were PPFM 16, PPFM 26, PPFM 35, PPFM 37 and PPFM 38.

The seeds were treated with 1 per cent PPFM solution by soaking the seeds overnight in the respective isolates. The medium used for the study was sandy clay loam soil collected from paddy field. The soil was moderately acidic in reaction $(\mathrm{pH}$ - 6.05) with normal electrical conductivity $\left(0.24 \mathrm{dS} \mathrm{m}^{-1}\right)$.

The emergence characters were observed for/ upto 14 days after sowing (DAS). The data generated were statistically analysed using analysis of variance technique (ANOVA), as applied to completely randomized design (Gomez and Gomez, 2010).

\section{Results and Discussion}

\section{Emergence percentage and emergence rate index}

Irrespective of the PPFM isolates, hundred per cent emergence was observed (Table 1). Seeds treated with distilled water (control) recorded 92 per cent emergence. The emergence rate index was observed to be higher when the seeds were treated with PPFM 38 followed by PPFM 37. The mean emergence rate index was observed to be higher (149.6) with seed treatment of PPFM compared to control (121).

The increment observed may be due to the production of gibberellin (GA3) which improves the synthesis and secretion of the hydrolytic enzymes which mobilizes the endosperm storage reserves. This is turn would act as fuel for germination and growth (Cirac et al., 2004). 
In a similar experiment conducted in tomato, an increase in the germination percentage by 33.69 per cent was observed (Chandrasekaran et al., 2017). Holland (1997) reported that PPFMs could be used as seed coatings designed to enhance germination and vigour index.

\section{Shoot length and root length}

The PPFM isolates tested had no significant effect on the shoot length of rice seedlings as evidenced by the lack of significant difference between PPFM and control (Table 2). However the seedling root length varied significantly among the treatments.

Rice seeds treated with PPFM 38 recorded significantly longer roots for seedlings $(13.605 \mathrm{~cm})$. It was on a par with PPFM 16 and PPFM 26. The seedling root length recorded with PPFM 38 was 29.9 per cent greater than the control where the seeds were pre-treated with distilled water.

PPFMs have been reported to influence seed germination and seedling growth by producing plant growth regulators like zeatin and related cytokinins and auxins (Dourado et $a l ., 2015)$. This increment in the shoot length and root length might be due to, PPFM isolates which are capable of generating plant growth regulators such as auxin and cytokinin (Ivanova et al., 2000) which in turn induce cell division and cell elongation. Maximum shoot length $(9.47 \mathrm{~cm})$ and maximum root length $(18.38 \mathrm{~cm})$ was recorded in PPFM 26 treated seeds and PPFM 15 respectively (Riyas, 2019).

\section{Dry weight of seedling and seedling vigour}

Dry weight of rice seedlings was significantly higher (0.198 g per seedling) with PPFM 38 and it remained at par with the other PPFM isolates except control (Table 3). In general, seed treatment with PPFM recorded higher mean seedling dry weight $(0.184 \mathrm{~g}$ per seedling) compared to control $(0.135 \mathrm{~g}$ per seedling). Compared to control, seed treatment with PPFM 38 recorded 46.7 per cent increase in seedling dry weight.

Seed treatment with PPFM had significant effect on the seedling vigour expressed as vigour indices. Seedling vigour index I based on shoot length and germination percentage was significantly higher for PPFM 38 (2666.50), which was comparable with PPFM 35 and PPFM 37. Seed treatment with distilled water (control) recorded the lowest vigour index.

Table.1 Effect of PPFM on emergence percentage and emergence rate index

\begin{tabular}{|l|c|c|}
\hline Treatment & $\begin{array}{c}\text { Emergence } \\
\text { percentage }\end{array}$ & $\begin{array}{c}\text { Emergence rate } \\
\text { index }\end{array}$ \\
\hline PPFM 16 & 100 & 152 \\
\hline PPFM 26 & 100 & 133 \\
\hline PPFM 35 & 100 & 147 \\
\hline PPFM 37 & 100 & 156 \\
\hline PPFM 38 & 100 & 160 \\
\hline Control & 92 & 121 \\
\hline
\end{tabular}


Table.2 Effect of PPFM on shoot length and root length of rice seedlings

\begin{tabular}{|l|c|c|}
\hline Treatment & Shoot length $(\mathbf{c m})$ & $\begin{array}{c}\text { Root length } \\
\text { (cm) }\end{array}$ \\
\hline PPFM 16 & 23.685 & 13.440 \\
\hline PPFM 26 & 22.840 & 12.435 \\
\hline PPFM 35 & 24.600 & 10.705 \\
\hline PPFM 37 & 26.425 & 11.045 \\
\hline PPFM 38 & 26.665 & 13.605 \\
\hline Control & 23.710 & 10.475 \\
\hline SE m ( $\mathbf{( )}$ & 0.958 & 0.690 \\
\hline CD $(\mathbf{0 . 0 5})$ & NS & 2.0920 \\
\hline
\end{tabular}

Table.3 Effect of PPFM on dry weight of seedling, seedling vigour index I and seedling vigour index II of rice

\begin{tabular}{|l|c|c|c|}
\hline Treatment & $\begin{array}{c}\text { Dry weight of } \\
\text { seedling } \\
\text { (g per seedling) }\end{array}$ & $\begin{array}{c}\text { Seedling vigour } \\
\text { index I }\end{array}$ & $\begin{array}{c}\text { Seedling vigour } \\
\text { index II }\end{array}$ \\
\hline PPFM 16 & 0.168 & 2368.00 & 16.75 \\
\hline PPFM 26 & 0.188 & 2284.00 & 18.75 \\
\hline PPFM 35 & 0.178 & 2460.00 & 17.75 \\
\hline PPFM 37 & 0.190 & 2642.00 & 19.75 \\
\hline PPFM 38 & 0.198 & 2666.50 & 19.00 \\
\hline Control & 0.135 & 2133.93 & 12.15 \\
\hline SE (m) & 0.011 & 95.39 & 1.05 \\
\hline CD (0.05) & 0.0320 & 285.642 & 3.145 \\
\hline
\end{tabular}

Seedling vigour index II computed based on dry weight and germination percentage was significantly higher for PPFM 37 (19.75). However, it was on a par with the other PPFM isolates except control. Sundaram et al., (2002) observed that the production of plant hormones and vitamins by PPFM colonizing the phyllosphere regions of maize, has enhanced the seedling vigour of maize. In a similar experiment conducted by Madhaiyan (2003) in cotton, a significant increase in the dry matter production was observed when compared to the control.

Seed treatment with pink pigmented facultative methylotrophs was observed to increase the emergence potential and seedling vigour of rice. The enhanced seedling vigour can be translated into improved crop growth and yield under field conditions.

\section{References}

Chandrasekaran, P., Sivakumar, R., Nandhitha, G.K., Vishnuveni, M., Boominathan, P., and Senthilkumar, M. 2017. Impact of PPFM and PGRs on seed germination, stress tolerant index and catalase activity in tomato (Solanum lycopersicum L.) under drought. Inter. J. Curr. Microbiol. Appl. Sci. 6 (6): 540-549.

Cirac, C., Ayan, A.K., and Kevseroglu, K. 2004. The effects of light and some 
presoaking treatments on germination rate of St. John worth seeds. Pak. J. Biol. Sci. 7: 182-186.

Dourado, M.N., Neves, C.A.A., Santos, D.S., and Araujo, W.L. 2015. Biotechnological and agronomic potential of endophytic pink pigmented methylotrophic Methylobacterium spp. Biomed. Res. Int. 2015: 909-916.

Freyermuth, S.K., Long, R.L., Mathur, S., Holland, M.A., Holstford, T.P., Stebbins, N.E., Morris R.O., and Polacco, J.C. 1996. Metabolic aspects of plant interaction with commensal methylotrophs. In: Lindstorm, M. and Tabita, R. (eds), Microbial Growth on $\mathrm{Cl}$ Compounds, Kluwer Academic Publishers, New York, pp 21-134.

Gomez, K.A. and Gomez, A.A. 1984. Statistical Procedure for Agricultural Research. John Wiley and Sons, Inc., New York, pp. 67-215.

Holland, M.A. 1997. Occams razor applied to hormonology. Are cytokinins produced by plants. Plant. Physiol. 115: 865-868.

Ivanova, E.G., Dornina, N.V.,
Shepelyakovskaya, A.O., Laman, A.G., Brovko, F. A., and Trotsenko, Y.A. 2000. Facultative obligate aerobic methylobacteria synthesize cytokenins. Microbiol. 69: 646-651.

Kamoshita, A., Babu, R.C., Boopathi, N.M., and Fukai, S. 2008. Phenotypic and genotypic analysis of drought-resistance traits for development of rice cultivars adapted to rainfed environments. Field Crops Res. 109:1-23.

Madhayian, M. 2003. Molecular aspects, diversity and plant interactions of facultative methylotrophs occurring in tropical plants. Ph. D. thesis, Tamil Nadu Agricultural University. Coimbatore, $183 \mathrm{p}$.

Riyas, N.K. 2019. Screening of pink pigmented facultative methylotroph (PPFM) isolates for water stress tolerance and yield in paddy. M. Sc. (Ag.) thesis, Kerala Agricultural University, Thrissur, 199p.

Sundaram, S. P., Madhaiyan, M., Senthilkumar, M., and Reddy, B. V. S. 2002. A novel microbial symbiont for using as a bioinoculant. In: Chendrayan, K., Ilamurugu, Z., Kennedy, J., and Govindarajan, K. (eds), Microbial Transformations in Soil. Tamil Nadu Agricultural University, Coimbatore, India, pp. 123-131.

Van Dein, S. J., Okubo, Y., Hough, T. M., Korotkova, N., Taitano, T., and Lidstrom, M. E. 2003. Reconstruction of $\mathrm{C}_{3}$ and $\mathrm{C}_{4}$ metabolism in Methylobacterium extorques AM1 using transposon mutagenesis. Microbiol.149 (3): 601-609.

\section{How to cite this article:}

Aswathy. J. C., P. Shalini Pillai, Jacob John and Meenakumari. K. S. 2020. Effect of Pink Pigmented Facultative Methylotrophs on Seedling Emergence and Vigour of Rice (Oryza sativa L.). Int.J.Curr.Microbiol.App.Sci. 9(07): 442-446.

doi: https://doi.org/10.20546/ijcmas.2020.907.049 